\title{
Methods of establishing tall fescue and ryegrass in a dryland environment
}

\author{
D.E. HUME and T.B. LYONS \\ AgResearch, Grasslands Research Centre, Private Bag 11008, Palmerston North
}

\begin{abstract}
Optimal systems for establishing new pastures were considered at trial sites in southern Hawkes Bay and Manawatu. Systems of pasture establishment, before drilling new pasture in autumn, were: (a) spring sown barley, (b) summer fallow by cultivation, (c) summer fallow by glyphosate spraying, and (d) pasture during summer then a single glyphosate spray at drilling. Each establishment treatment was sown with white/sub clover, and either tall fescue (an example of a dryland grass species) or perennial ryegrass. Methods (a) and (b) used a roller drill to sow pastures into a cultivated seedbed, and methods (a), (c) and (d) used a direct drill. A very moist cool summer resulted in no advantage to the fallow treatments in terms of better soil moisture at sowing, but generally these treatments had the best establishment, possibly due to low weed contents and higher soil nitrogen levels. A single spray with glyphosate before direct drilling gave the poorest results for both grass species. The relative advantages and disadvantages of each treatment are discussed. Establishment and yields of tall fescue were lower than for ryegrass, although tall fescue had higher white/sub clover contents and less dead matter than ryegrass pastures. A low sowing rate and colder-than-average temperature at sowing may have depressed the establishment of tall fescue. Ryegrass quickly recovered from lower levels of establishment (within 3-6 months) but tall fescue took 9-12 months to show any improvement in contribution to pasture yields.
\end{abstract}

Keywords: dryland, Festuca arundinacea, Lolium perenne, pasture establishment

\section{Introduction}

Establishment of new pastures in dryland environments can be difficult, as ideal conditions for seedling growth, e.g., a warm moist seedbed, are rarely present unless farmers adequately plan and action a number of management steps before sowing (Milne \& Fraser 1990). This is most critical for "alternative" dryland grass species, such as tall fescue (Festuca arundinacea Schreb.), cocksfoot (Dactylis glomerata L.) and phalaris
(Phalaris aquatica L.), that are generally slower to germinate and establish than ryegrass (Lolium spp.) (Brock 1983). Compared with ryegrass, these species are greatly affected by decreasing soil temperatures and soil moisture (McWilliam et al. 1970; Charlton $\boldsymbol{e t}$ al. 1986).

Several management options exist for establishing pasture species in dryland environments. These options affect critical factors for successful establishment such as soil moisture, potential soil loss by erosion, sowing depth, sowing time and weed control (Milne \& Fraser 1990). Optimal systems for establishment of alternative species in dryland were considered at a trial site in southern Hawkes Bay, with further reference being made to a similar trial in Manawatu.

\section{Materials and methods}

\section{Dannevirke trial}

(a) Site The trial was situated $12 \mathrm{~km}$ south south-west of Dannevirke in the Oringi district, on a stony Takapau silt loam soil. In August 1991, soil pH was 6.0, P retention 40, with moderate $\mathrm{P}$ (12 Olsen $\mathrm{P})$, low $\mathrm{S}$ (3, Quick test units), and moderate to high levels (Quick test units) of $\mathrm{Mg}$ (21) and $\mathrm{K}$ (8). Species composition of the pasture was $44 \%$ ryegrass. $37 \%$ other grasses (mainly browntop (Agrostis tenuis Sibth.)), and 16\% white clover.

Average lo-year rainfall was $850 \mathrm{~mm}$, approximately $>30 \%$ of this occurring in winter and $<20 \%$ in summer. Low summer rainfall and a high westerly wind run commonly results in a summer drought. Without irrigation, ryegrass pastures fail to persist, and an ingress of browntop results within 3-4 years. The farm has one paddock in the Drought Pasture Demonstration Programme.

(b) Pre-sowing treatments During late winter/early spring 1991 the pasture was set stocked with ewes and lambs. The pasture was then subjected to the following 5 treatments (main plots) during spring 1991/summer 1991-92, before sowing new pastures in early autumn 1992 (treatment details in Table 1) (treatment names used hereafter in parentheses):

(1) Spring-sown barley, and new pasture direct drilled into stubble and straw (Barley/Direct Drill - B/ DD). 
Table 1 Sequence of events at the Dannevirke trial for each treatment, before drilling new tall fescue and ryegrass pastures on 4 March 1992.

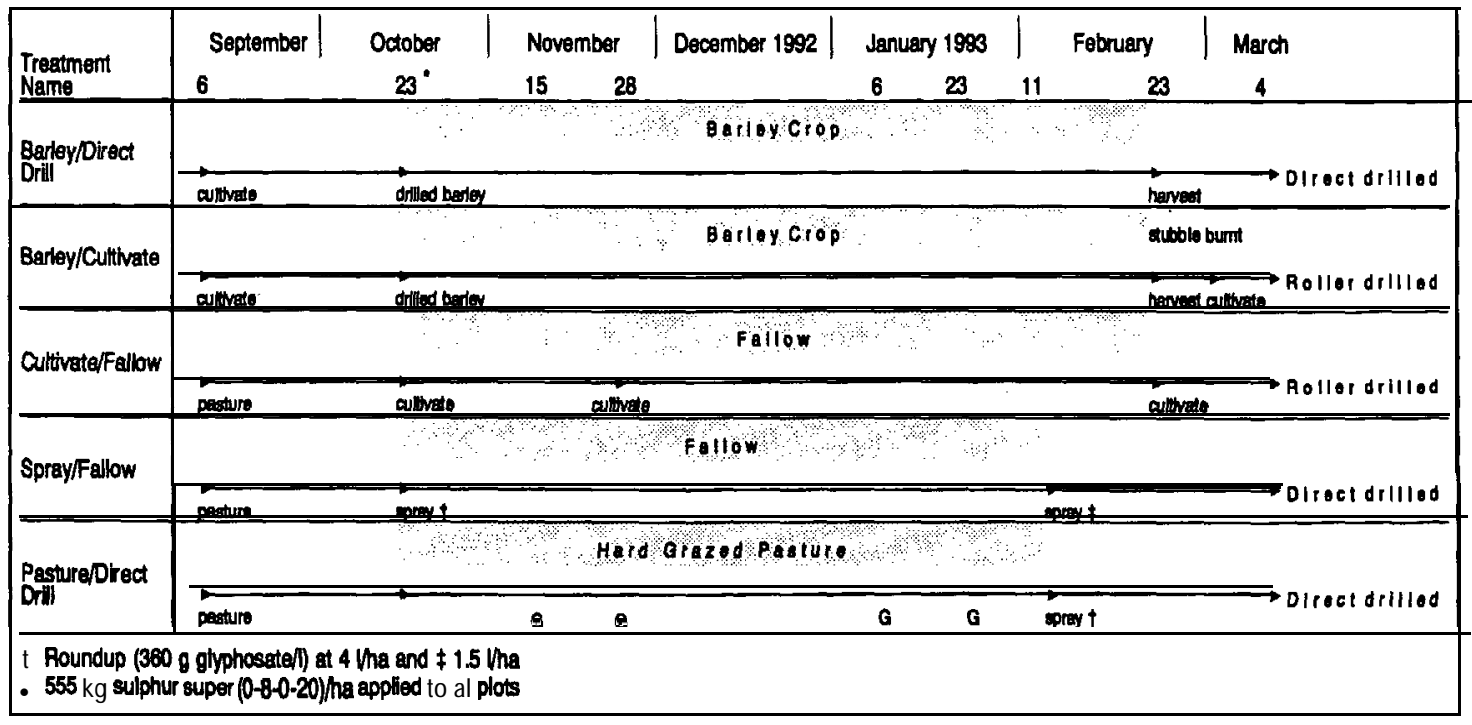

(2) Spring-sown barley, and new pasture drilled into cultivated seedbed (Barley/Cultivate $-\mathrm{B} / \mathrm{C}$ ).

(3) Fallow during late spring/summer by cultivating, and new pasture drilled into cultivated seedbed (Cultivate/Fallow - C/F).

(4) Fallow during late spring/summer by spraying herbicide (glyphosate), and new pasture direct drilled (Spray/Fallow - S/F).

(5) Pasture was rotationally grazed during spring and summer to a low residual pasture cover $(1-2 \mathrm{~cm}$ height) with sheep at stocking rates equivalent to 800-1000 ewes/ha, then sprayed with glyphosate immediately before direct drilling new pasture (Pasture/Direct Drill - P/DD).

These main plots $\left(750 \mathrm{~m}^{2} / \mathrm{plot}\right)$ were replicated 4 times in a randomised block design.

(c) Species treatments At sowing on 4 March 1992, main plots were split and the subplots $\left(375 \mathrm{~m}^{2} /\right.$ subplot) sown with either:

(1) Grasslands Roa tall fescue (Festuca arundinacea Schreb.), or

(2) 'Grasslands Pacific' perennial ryegrass (Lolium perenne L.) (infected with an 'Endosafe ${ }^{\mathrm{TM}}$, fungus).

Sowing rates for tall fescue and ryegrass were 26 $\mathrm{kg} / \mathrm{ha}(90 \%$ germination) and $21 \mathrm{~kg} / \mathrm{ha}(75 \%$ germination), respectively, in the cultivated plots, but a calibration error in the direct-drilled plots resulted in lower sowing rates of $16 \mathrm{~kg} / \mathrm{ha}$ and $15 \mathrm{~kg} / \mathrm{ha}$ respectively. All plots were also sown with $2 \mathrm{~kg} / \mathrm{ha}$ of Tallarook sub clover ( $T$. subterraneum L.) and $3 \mathrm{~kg} / \mathrm{ha}$ of white clover (Trifolium repens L.) (mixture of cultivars Grasslands Kopu and Grasslands Tahora in the ratio of 1:2). Cultivated plots were sown with a roller drill followed by chain harrows. Direct-drilled plots were sown with a winged chisel coulter (Aitchison Seedmatic 800) creating an inverted T-shaped groove, followed by chain harrows and a Cambridge roller.

(c) Pest control Three weeks prior to sowing (late February), pest numbers where determined by inspecting the soil in spade squares $(30 \mathrm{~cm} \times 30 \mathrm{~cm}$ squares to 20 $\mathrm{cm}$ depth) and inspecting under wet sacks on the ground. In the $\mathrm{S} / \mathrm{F}$ and $\mathrm{P} / \mathrm{DD}$ treatments, $20-40$ porina (Wiseana cervinata Walker) caterpillars $/ \mathrm{m}^{*}$ were found, and so these treatments were treated with diazinon granules at $2 \mathrm{~kg}$ a.i./ha immediately after sowing. In April, patches of grass grub (Costelytra zealandica White) damage became evident in some treatments (40 grubs $\left./ \mathrm{m}^{2}\right)$, and although all plots were treated with granules of isazophos at $2 \mathrm{~kg}$ a.i./ha on 6 May, further sampling on 3 June showed $30-50$ grubs $/ \mathbf{m}^{2}$.

(d) Post sowing management Subplots were separately fenced and grazed with ewes at stocking rates equivalent to 500-800 ewes/ha when pastures reached $10-15 \mathrm{~cm}$ height. This resulted in varying intervals between grazings for some treatments to enable the appropriate grazing management for the best possible establishment 
for each pre-sowing treatment or species. P/DD and the two barley treatments were grazed 2 and 3 months after sowing, respectively, to control growth of goose grass (Bromus mollis L.) and barley seedlings, respectively. All treatments were grazed 3.5 months after sowing. For the subsequent grazings until 12 months after sowing, tall fescue plots were grazed on 5 occasions and ryegrass on 6 .

Four weeks after sowing, nitrogen was applied to tall fescue plots at a rate of $25 \mathrm{~kg} / \mathrm{ha}$ as urea, and all plots were heavy rolled to push stones back into the ground.

(e) Measurements Immediately after sowing, gravimetric soil moisture content was determined for six 10 $\mathrm{cm}$ deep soil cores per main plot. At the same time, 1 soil sample $(20 \mathrm{~cm} \times 20 \mathrm{~cm}$ to $20 \mathrm{~cm}$ depth $)$ from each main plot treatment of 1 replicate was analysed for aggregate size and stability. Tall fescue and ryegrass seedling populations (ten $0.125 \mathrm{~m}^{2}$ quadrats per plot) and numbers of leaves, tillers and dry weights per seedling were determined 3-4 weeks after sowing.

Pasture yields and composition were determined by cutting pasture to $3 \mathrm{~cm}$ height after each grazing from two $0.25 \mathrm{~m}^{2}$ grazing exclosure cages per plot. Grass tiller, clover growing points and weed plant populations were assessed 14 months after sowing (autumn 1993) from 50 tiller plugs $\left(20 \mathrm{~cm}^{2} / \mathrm{plug}\right.$ ) per plot.

\section{Manawatu trial}

This trial was sited at the AgResearch Aorangi Lowland Research farm, Manawatu, and had 8 treatments during spring/summer before sowing new ryegrass pastures in autumn 1992. These treatments and site details are described by Hume \& Lyons (1992). This trial was also repeated the following year (1992/93). Three of these treatments (Table 6) were essentially the same as those described above for the Dannevirke trial. There was an additional treatment in which pasture that had been hard grazed during spring/summer was sprayed with glyphosate and cultivated 3-4 weeks before sowing in autumn (P/C treatment).

Measurements taken 1-2 months after sowing were gravimetric soil moisture, soil nitrate content $(15 \mathrm{~cm}$ depth), nitrogen content of ryegrass leaf lamina, and herbage yields.

\section{Rainfall and temperature}

Meteorological data were obtained from the Oringi farm rainfall records, $1 \mathrm{~km}$ from the Dannevirke trial, and the Kairanga meteorological station, $1 \mathrm{~km}$ from the Manawatu trial.

\section{Results and discussion}

\section{Seedbed conditions at sowing}

In both years and at both sites, soil moisture at sowing was high (26\% and 33\% at Dannevirke and Manawatu trials, respectively), reflecting the results of several cool, wet years (temperatures $1.5-2^{\circ} \mathrm{C}$ below long-term means, $25-70 \%$ more rain than average). This negated the advantage that summer fallowing can have in conserving and accumulating soil moisture during summer in dry years and in dryland environments. Scott \& Brown (1979) reported that summer fallowing can double the soil moisture at sowing, resulting in 3 times the autumn-spring yields of Tama ryegrass compared with a non-fallowed area.

Although sowing was conducted in early autumn, the low temperatures meant that the sowing time was equivalent to mid autumn in a year with 'average' temperatures. From farmers' experiences in dryland areas, Milne \& Fraser (1990) and Milne et al. (1993) recommended that alternative grass species such as tall fescue should be sown in early autumn, as generally these species are greatly affected by low temperatures at establishment (Charlton et al. 1986).

At sowing in the Darmevirke trial, soil under direct drilled pastures (S/F, P/DD) was more stable (high value for net $\%$ aggregation $0.5 \mathrm{~mm}$ ) and had a greater aggregate size (higher negative value for mean weight diameter) (Table 2), and so was less liable to erosion. The cultivations involved with the barley crops decreased soil stability and aggregate size, making these treatments most liable to wind or water erosion. The soil in all treatments was still relatively stable but the results illustrate the effect that different pre-sowing treatments can have on the potential erodibility of a soil. Major soil loss from erosion is relatively infrequent but can be disastrous. Thus in situations such as hill slopes, paddocks exposed to high wind runs, or on relatively unstable soils, direct drilling would help to minimise the risk of soil erosion.

\section{Seedling growth: Dannevirke trial}

Treatments where seed was sown into a cultivated seedbed $(\mathrm{B} / \mathrm{C}, \mathrm{C} / \mathrm{F})$ had a higher \% emergence of seed sown (mean 75\%) than in direct-drill treatments (mean $58 \%$ ), but seedling weight and size were lower (Table 3). Milne et al. (1993) also reported lower \% emergence in direct-drilled pastures on farms in the Hawkes Bay and Gisbome regions. For all pre-sowing treatments, emergence of ryegrass seed was greater than that of tall fescue, and ryegrass seedlings were larger for all measured parameters (Table 3). Tall fescue seedlings have poor early growth (Brock 1983), highlighting the need for a long establishment period. 
Table 2 Soil aggregate stability (net \% aggregation from wet sieving) and soil aggregate size. (phi values) at the autumn sowing of new pasture at Dannevirke.

\begin{tabular}{|c|c|c|c|c|c|c|c|}
\hline \multirow{2}{*}{$\begin{array}{l}\text { Treatment } \\
\text { Barleyl }\end{array}$} & \multicolumn{3}{|c|}{-Nel \% Aggregation- } & \multicolumn{4}{|c|}{ - -...Aggregate Sizenumun } \\
\hline & & & & & & & \\
\hline $\begin{array}{l}\text { Direct Drill } \\
\text { Barleyl }\end{array}$ & 51.1 & 74.3 & 64.9 & -0.66 & -0.14 & 0.04 & -0.76 \\
\hline $\begin{array}{l}\text { Cultivate } \\
\text { Cultivatel }\end{array}$ & 56.4 & 71.4 & 62.5 & -0.76 & -0.06 & 0.04 & -0.79 \\
\hline $\begin{array}{l}\text { Fallow } \\
\text { Sprayl }\end{array}$ & 71.6 & 62.3 & 69.9 & -0.93 & -0.06 & -0.03 & -0.96 \\
\hline $\begin{array}{c}\text { Fallow } \\
\text { Pasturel }\end{array}$ & 76.1 & 69.3 & 93.5 & -0.99 & -0.06 & 0.02 & -1.05 \\
\hline Direct Drill & 03.5 & 69.9 & 93.2 & -1.09 & -0.04 & 0.01 & -1.11 \\
\hline
\end{tabular}

Table 3 Sown grass \% emergence of viable seed sown, seedling weight and size 4 weeks after the autumn sowing of new pasture at Dannevirke. Means accompanied by the same letter in a column are not different $(P>0.05$, for transformed data).

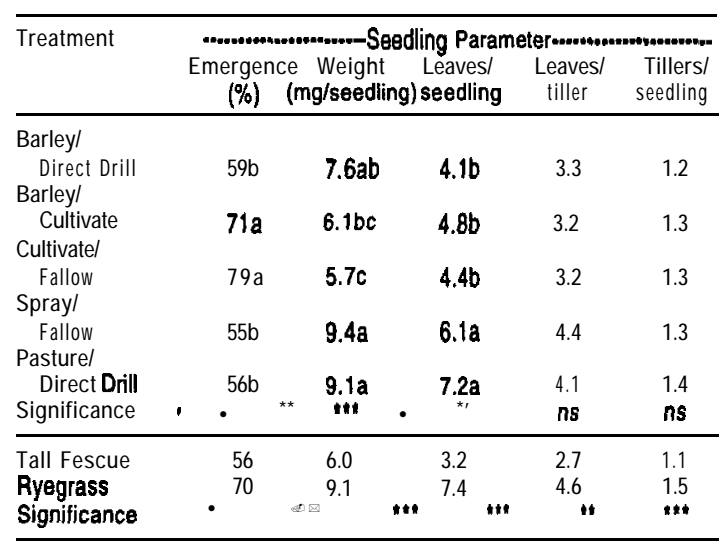

Yields and botanical composition: Dannevirke trial Initially, the $\mathrm{C} / \mathrm{F}$ treatment had the highest contents of tall fescue and ryegrass, followed by lower contents in the S/F and barley treatments, and lowest content in the P/DD (Figure 1). The slow early growth and lower \% emergence of tall fescue was evident in its low contribution to total yields during the first year (Figure la). In contrast, ryegrass had a high contribution to yields within 3-6 months (Figure lb). However, tall fescue and ryegrass responded differently to the presowing treatments (significant species $\mathrm{x}$ pre-sowing treatment interaction, $\mathrm{P}<0.01$ ) (Figure 1).

During winter and spring, ryegrass improved so that by summer, ryegrass yield and ryegrass content were similar in all treatments except the P/DD. Ryegrass tiller populations (mean $9600 / \mathrm{m}^{2}$ ) 1 year after sowing were also similar in all treatments $(P>0.05)$. In contrast,
Figure 1 Percentage tall fescue (A) and ryegrass (B) of the total green yield for tall fescue and ryegrass based pastures respectively at Dannevirke. Barley/Direct Drill (A), Barley/Cultivate (A), Cultivate/Fallow (Cl), Spray/ Fallow(m), Pasture/Direct Drill (o).

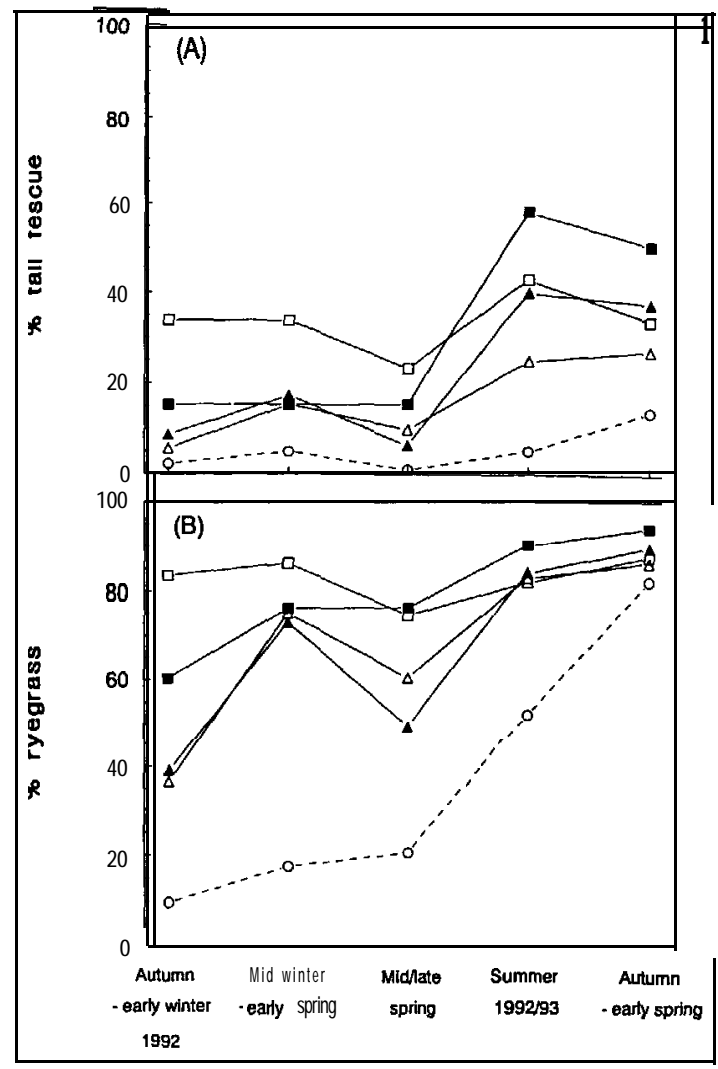

tall fescue contents increased only in summer but not in the P/DD. The best overall results for tall fescue occurred in the $S / F$ treatment, with tiller numbers similar to those in the ryegrass treatments (Table 4) ( $>0.05$ ).

These results demonstrated the ability of ryegrass to quickly overcome low initial establishment. Tall fescue needed a greater time to establish and increase its contribution to pasture yields, but this was not always possible where initial establishment was low and competition strong, i.e., P/DD. Similar results have been reported for tall fescue and ryegrass by Hume \& Chapman (1993), while McCallum \& Thomson (1990) recommended that tall fescue should not be established by the P/DD method.

Total green yield over the first year of the trial was highest in the P/DD and S/F treatments (Table 4), with no significant differences between tall fescue and ryegrass pastures. P/DD established a rapid pasture cover, primarily goose grass seedlings (3400 seedlings/ 
Table 4 Total green yield ( $\mathrm{kg} \mathrm{DM} / \mathrm{ha}$ ) for the 12 months after sowing in autumn 1992, and tall fescue tillerpopulation in autumn 1993 at Dannevirke. Means accompanied by the same letter in a row are not different $(\mathbf{P}>0.05$. Transformed data for tillers).

\begin{tabular}{|c|c|c|c|c|c|c|}
\hline \multirow{3}{*}{ Season } & \multicolumn{3}{|c|}{..................n+m.Pre-sowing } & \multicolumn{3}{|c|}{ 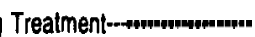 } \\
\hline & Barleyl & Barleyl C & Cultivatel & Sprayl & Pasturel & Signil. \\
\hline & $\begin{array}{l}\text { Direct } \\
\text { Drill }\end{array}$ & Cultivate & Fallow & Fallow & $\begin{array}{l}\text { Direct } \\
\text { Drill }\end{array}$ & \\
\hline \multicolumn{7}{|l|}{ Autumn/ } \\
\hline Mid winterl & & IJIUC & 13000 & 194010 & & \\
\hline early spring & $570 \mathrm{c}$ & $720 \mathrm{bc}$ & $1160 \mathrm{~b}$ & $1760 \mathrm{a}$ & $1690 \mathrm{a}$ & ttt \\
\hline spring & $2340 \mathrm{c}$ & $2520 \mathrm{c}$ & $2620 \mathrm{c}$ & $3260 \mathrm{~b}$ & $3610 a$ & n' \\
\hline Summer & 2630 & 3170 & 2670 & 3310 & 2610 & $\mathrm{~ns}$ \\
\hline $\begin{array}{r}\text { Total for } \\
\text { year } 1\end{array}$ & \multicolumn{2}{|c|}{ Total for } & $7610 \mathrm{~b}$ & $10290 a$ & $11340 a$ & a "1" \\
\hline $\begin{array}{r}\text { Tall fescue } \\
\text { tillers } / m^{2}\end{array}$ & $5270 \mathrm{~b}$ & $1600 c^{2}$ & $2660 \mathrm{~b}$ & $8110 a$ & $460 \mathrm{~d}$ & $m$ \\
\hline
\end{tabular}

$\mathbf{m}^{2}$ ), which although competitive towards the establishing seedlings, resulted in high total yields in winter and spring. In contrast, high total yields in $S / F$ corresponded with the highest yields of ryegrass and tall fescue. Lower initial growth and seedling establishment in the barley treatments reflected the strong competition that the sown species faced from barley regrowth (3046\% of total yield) from barley seed germinating on the soil surface. Milne \& Fraser (1990) also experienced this problem when ryecorn, Italian ryegrass or oats had been sown. Barley regrowth also contributed to a high dead content $(29 \%)$ in the barley treatments during autumn/winter. B/DD also suffered greater grass grub damage.

Tall fescue pastures had higher contents of weeds, white and sub clover, and less dead matter than ryegrass pastures (Table 5). This is consistent with other experiments in which tall fescue and ryegrass based pastures have been compared (e.g., Goold \& van der Elst 1980; Wright et al. 1985).

The lack of significantly higher yield of the tall fescue pastures compared with the ryegrass pastures is not unexpected, as the unusually cool moist summer in the year after establishment favoured the growth of all species. The major advantage of tall fescue in this region occurs during years of summer drought, while ryegrass performs poorly under these conditions (Hume et al. 1993). Tall fescue also performs better in soils of higher fertility (e.g., Olsen P > 18) and a history of good clover growth (A110 \& Southon 1968; Milne pers. comm.), than occurred at this site.

Despite the use of pre-sowing treatments, shown previously in the Manawatu to allow very little natural
Table 5 Mean annual contribution to yield (\%) of other grasses, clover, weeds and dead, and white clover growing points (autumn 1993) for each pasture type at Daanevirke.

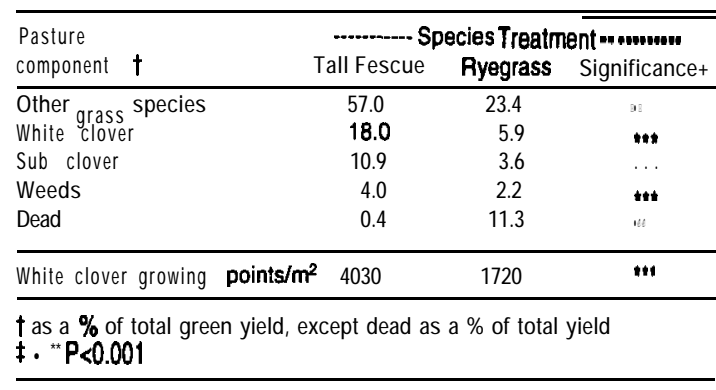

Table 6 Nitrogen contents and yields after the autumn sowing of new pasture in the Manawatu in 1992 and 1993.

\begin{tabular}{|c|c|c|c|c|c|}
\hline \multirow[t]{2}{*}{ Treatment } & \multicolumn{2}{|c|}{$\begin{array}{l}\text { Soil nitrate } \\
\ldots(p p m) \ldots \ldots .\end{array}$} & \multicolumn{2}{|c|}{ Herbage nitrogen } & \multirow{2}{*}{$\begin{array}{c}\text { Total yield } \\
--(\mathrm{kg} \mathrm{DM} / \mathrm{ha})-- \\
1992 \quad 1993\end{array}$} \\
\hline & 1992 & 1993 & 1992 & 1993 & \\
\hline \multicolumn{6}{|l|}{ Barleyl } \\
\hline Cultivate & 83 & $53 a$ & $4 \cdot 2$ & $\begin{array}{ll}6 & 4.86\end{array}$ & b 2293abt n.m. $\dagger$ \\
\hline \multicolumn{6}{|l|}{ Sprayl } \\
\hline Fallow & 74 & $56 a$ & 4.43 & $5.19 a b 2$ & $699 a 3240 a$ \\
\hline \multicolumn{6}{|l|}{ Pasturel } \\
\hline $\begin{array}{l}\text { Direct Drill } \\
\text { Pasture/ }\end{array}$ & 43 & $20 \mathrm{~b}$ & 3.47 & $4.39 c$ & $2192 b \quad 3950 a$ \\
\hline Cultivate & n.m. & $40 a b$ & n.m. & $5.33 a$ & 1991 b $1660 b$ \\
\hline
\end{tabular}

$\dagger 50.60 \%$ of yield was barley regrowth from seed

$n . m$. Not measured

reseeding of ryegrass (Hume \& Lyons 1992), all tall fescue pastures had significant contämination from ryegrass. With the slow early growth of iall fescue a small component of ryegrass in autumn/winter (mean, $3 \%$ of green yield) had increased to 39\% (range $\mathbf{2 5}$ $56 \%$ ) by summer, with 8500 ryegrass tillers $/ \mathrm{m}^{2}$ in autumn 1993. Cultivated treatments had higher levels than direct-drilled treatments, and P/DD had higher levels than summer-fallowed treatments. In a dryland environment, ryegrass seed buried in the soil may be surviving for over 12-18 months, a factor that should be considered when a seedbed free of ryegrass is required.

The ryegrass content of tall fescue pastures indicates that resident ryegrass may have also been contributing to ryegrass yields in the ryegrass sown pastures. This may have been a significant proportion in the P/DD treatment as this had high ryegrass tiller populations, similar to the other ryegrass treatments $(P>0.05)$, but still low ryegrass yields. Resident ryegrass typically has higher numbers of tillers per plant but very small tillers. 


\section{Manawatu trial}

At the first grazing after sowing in autumn, the $S / F$ treatment had high total yields and contents of ryegrass ( $97 \%$ ), with $\mathrm{P} / \mathrm{C}$ the lowest yields and ryegrass contents (87\% ryegrass) (Table 6). Yields of the P/DD treatment were intermediate or high, but as had occurred at Dannevirke, the extra yield was mostly due to other species (54\%) (primarily Poa annua L.) and yields of ryegrass were similar to the $\mathrm{P} / \mathrm{C}$. These results could have been due to higher levels of available soil $\mathrm{N}$ (nitrate), although herbage $\mathrm{N}$ contents do not indicate that $\mathrm{N}$ was limiting growth (Table 6).

\section{Conclusions}

These trials have illustrated some of the effects that pre-sowing management can have on conditions at sowing, and during establishment of a pasture. Advantages and disadvantages of each pre-sowing management are listed in Table 7 , including those obtained in dry years and experience gained on farms during the Pasture Drought Demonstration Programmes (Milne \& Fraser 1990; Milne et al. 1993). In a dryland environment, treatments that conserve soil moisture are critical especially when an early autumn sowing is required for good establishment of alternative dryland grass species. We conclude that a summer fallow either by spraying or cultivating are the best methods of establishing new pasture. This is most critical for tall fescue. Summer fallowing by spraying will be useful where soil erosion may be a problem.
Table 7 Relative advantages and disadvantages of each pre-sowing management for establishing new pasture in autumn.

\begin{tabular}{|c|c|c|}
\hline Pm-sowing Treatment & Advantages & Disadvantages \\
\hline Spring Barley & $\begin{array}{l}\text { - high cash return } \\
\text { - friable seed bed for } \\
\text { new pasture } \\
\text { - weed control } \\
\text { - grass seedhead } \\
\text { control } t \\
\text { - good control of most } \\
\text { insect pests }\end{array}$ & $\begin{array}{l}\text { - low soil moisture } \\
\text { - competition from regrowth } \\
\text { barley } \\
\text { - depletion of soil N } \\
\text { - late harvest leads to late } \\
\text { sowing date }\end{array}$ \\
\hline Cultivate/Fallow $\ddagger$ & $\begin{array}{l}\text { - conserves soil moisture } \\
\text { - weed control } \\
\text { - grass seedhead control } \\
\text { - good control of most } \\
\text { insect pests } \\
\text { - build up of soil N }\end{array}$ & $\begin{array}{l}\text { - no summer grazing } \\
\text { - costs of cultivation } \\
\text { - higher erosion potential } \\
\text { - poor control of rhizomatous } \\
\text { weeds unless sprays used } \\
\text { prior to cultivation }\end{array}$ \\
\hline $\begin{array}{l}\text { Spray/Fallowl } \\
\text { Direct Drill }\end{array}$ & $\begin{array}{l}\text { - conserves soil moisture } \\
\text { - good weed control } \\
\text { - grass seedhead control } \\
\text { - lower erosion potential } \\
\text { - build up of soil N } \\
\text { - reliable spray results }\end{array}$ & $\begin{array}{l}\text { - no summer grazing } \\
\text { - costs of sprays } \\
\text { - may need chemicals for } \\
\text { control of insect pests }\end{array}$ \\
\hline $\begin{array}{l}\text { Pasture/Sprayl } \\
\text { Direct Drill }\end{array}$ & - summer grazing & $\begin{array}{l}\text { - poor weed control } \\
\text { - low soil moisture } \\
\text { - difficult to control grass } \\
\text { seedheads } \\
\text { - may need chemicals for } \\
\text { control of insect pests } \\
\text { - low soil N } \\
\text { - variable spray results } \\
\end{array}$ \\
\hline \multicolumn{3}{|l|}{ Method of Sowing } \\
\hline Direct Drilling, with & $\begin{array}{l}\text { - less preparation time } \\
\text { - lower erosion potential } \\
\text { - good control of } \\
\text { perennial weeds }\end{array}$ & $\begin{array}{l}\text { - lower \% emergence } \\
\text { - more difficulty in achieving } \\
\text { correct sowing depth } \\
\text { - may need chemicals for } \\
\text { control of insect pests }\end{array}$ \\
\hline Cultivated seed bed $\ddagger$ & $\begin{array}{l}\text { - good control of sowing } \\
\text { depth (i.e. roller drill) } \\
\text { - good control of most } \\
\text { insect pests } \\
\text { - higher \% emergence }\end{array}$ & $\begin{array}{l}\text { - greater preparation time } \\
\text { - higher erosion potential }\end{array}$ \\
\hline
\end{tabular}

+ control of the formation of grass seedheads in spring, to reduce the natural reseeding that competes with new autumn pasture.

‡ recommended that a herbicide spray is used prior to cultivation to control rhizomatous grass and weeds.

\section{ACKNOWLEDGEMENTS}

We thank Ian Taylor, 'Oringi', Dannevirke, for his invaluable assistance and patience in the management of the trial on his property, and Grant Simpson for the cultivation work at 'Oringi'. This project was partially funded through the Technologies for Business Growth programme, by Aitchison Industries Ltd. and the Foundation for Research Science and Technology.

\section{REFERENCES}

Allo, A.V.; Southon, T. 1968. Experiences with $\mathbf{S 1 7 0}$ tall fescue. Proceedings of the New Zealand Grassland Association 29: 128-1 34.

Brock, J.L. 1983. 'Grasslands Roa' tall fescue: A review. Proceedings of the New Zealand Grassland Association 44: 74-80.

Charlton, J.F.L.; Hampton, J.G.; Scott, D.J. 1986. Temperature effects on germination of New Zealand 
herbage grasses. Proceedings of the New Zealand Grassland Association 47: 165-172.

Goold, G.J.; Van der Elst, F.C.C.H. 1980. The performance of Friesian steers grazing "Grasslands Roa" tall fescue pastures on peat soils in the Waikato. Proceedings of the New Zealand Grassland Association 41: 130- 137.

Hume D.E.; Chapman D.F. 1993. Oversowing of five grass species and white clover on a Taupo hill country pumice soil. New Zealand Journal of Agricultural Research 35: 309-322.

Hume, D.E.; Lyons, T.B. 1992. Establishment of new pastures free of ryegrass contamination. Proceedings of the New Zealand Grassland Association 54: 15 1156.

Hume, D.E.; Hay, R.J.M.; Lyons, T.B. 1993. Herbage and animal production from tall fescue and ryegrass based pastures in a summer dry environment. Proceedings of the XVII International Grassland Congress: 1322-1323.

McCallum, D.A.; Thomson, N.A. 1990. Effect of a mollusicide and an insecticide on the establishment of direct-drilled ryegrass, tall fescue and phalaris. Proceedings of the New Zealand Grassland Association 52: 237-240.

McWilliam, J.R.; Clements, R.J.; Dowling, P.M. 1970. Some factors influencing the germination and early seedling development of pasture plants. Australian journal of agricultural research 21: 19-32.

Milne, G.; Fraser, T.J. 1990. Establishment of 1600 hectares in dryland species around Oamaru/Timaru. Proceedings of the New Zealand Grassland Association 52: 133-137.

Milne, G.; Moloney, S.C.; Smith, D.R. 1993. Demonstration of dryland species on 90 east coast North Island farms. Proceedings of the New Zealand Grassland Association 55: (this volume).

Scott, W.R.; Brown, K.R. 1979. How good is Tama ryegrass? Proceedings of the New Zealand Grassland Association 40: 180- 183.

Wright, D.F.; Slay, M.W.A.; Hamilton, G.J.; Paterson, D.J. 1985. Tall fescue for finishing lambs and flushing ewes in Hawkes Bay. Proceedings of the New Zealand Grassland Association 46: 173-177. 